Note

\title{
SELECTION OF Beauveria bassiana (BALS.) VUILL. AND Metarhizium anisopliae (METSCH.) SOROK. FOR THE CONTROL OF THE MITE Mononychellus tanajoa (BONDAR)
}

\author{
Rodrigo Soares Barreto; Edmilson Jacinto Marques*; Manoel Guedes Corrêa Gondim Jr.; José \\ Vargas de Oliveira \\ UFRPE - Depto. de Agronomia - Fitossanidade, R. Dom Manoel de Medeiros s/n, Dois Irmãos - 52171-900 - \\ Recife, PE - Brasil. \\ *Corresponding author <emar@ufrpe.br>
}

\begin{abstract}
The green mite, Mononychellus tanajoa (Bondar) (Acari: Tetranychidae), is considered to be one of the key pests in cassava, Manihot esculenta Crants, leading to considerable field losses. In this study, ten Beauveria bassiana (Bals.) Vuill. and ten Metarhizium anisopliae (Metsch.) Sorok. isolates were evaluated with regard to their potential as biological control agents against adult $M$. tanajoa females. The total mortality percentage of M. tanajoa caused by B. bassiana ranged from 13.0 to $97.0 \%$, with confirmed mortality rates extending from 9.0 to $91.0 \%$ and $\mathrm{LT}_{50}$ varying from 4.2 to 17.0 days. The $M$. anisopliae isolates showed total mortality percentages ranging from 12.0 to $45.0 \%$ with confirmed mortality rates extending from 8.0 to $45.0 \%$, and $\mathrm{LT}_{50}$ varying from 8.6 to 19.8 days. Lethal Concentrations $\left(\mathrm{LC}_{50}\right)$ of $3.93 \times 10^{6}$ conidia $\mathrm{mL}^{-1}$ and $7.44 \times 10^{8}$ conidia $\mathrm{mL}^{-1}$ were determined for B. bassiana and M. anisopliae, respectively. B. bassiana isolate 645 was the most efficient, being an alternative for use in biological control programs against the cassava green mite.
\end{abstract}

Key words: entomopathogenic fungi, cassava green mite, microbial control

\section{SELEÇÃO DE Beauveria bassiana (BALS.) VUILL. E Metarhizium anisopliae (METSCH.) SOROK. PARA CONTROLE DO ÁCARO Mononychellus tanajoa (BONDAR)}

\begin{abstract}
RESUMO: O ácaro verde Mononychellus tanajoa (Bondar) (Acari: Tetranychidae) causa desfolhamento em mandioca Manihot esculenta Crants, proporcionando perdas na produção. Esse trabalho objetivou selecionar isolados dos fungos Beauveria bassiana (Bals.) Vuill. e Metarhizium anisopliae (Metsch.) Sorok. para utilização no controle desse ácaro. Foram utilizados dez isolados de B. bassiana e dez isolados de $M$. anisopliae, sobre fêmeas adultas de $M$. tanajoa. A percentagem de mortalidade total por B. bassiana variou de 13,0 a 97,0\%, com mortalidade confirmada de 9,0 a $91,0 \%$, e o tempo letal $\left(\mathrm{TL}_{50}\right)$ variou entre 4,2 e 17,0. Os isolados de $M$. anisopliae, provocaram 12,0 a 45,0\% de mortalidade total e 8,0 a 45,0\% de mortalidade confirmada e $\mathrm{TL}_{50}$ entre 8,6 e 19,8 dias. Estimaram-se os valores das concentrações letais $\left(\mathrm{CL}_{50}\right)$ de 3,93.10 ${ }^{6}{\text { conídios } \mathrm{mL}^{-1} \mathrm{e}}^{50}$ $7,44.10^{8}$ conídios $\mathrm{mL}^{-1}$, para os isolados 645 de B. bassiana e CG 321 de M. anisopliae, respectivamente. O isolado 645 de $B$. bassiana foi mais eficiente, sugerindo sua utilização em programas de controle biológico do ácaro verde da mandioca.

Palavras-chave: fungos entomopatogênicos, ácaro verde da mandioca, controle microbiano
\end{abstract}

\section{INTRODUCTION}

Brazil is one of the world's greatest cassava (Manihot esculenta Crantz) producers, with an annual yield of over 20 million tons, which places this crop among the main agricultural products explored in the country (FNP Consultoria e Comércio, 2002). Depending on the use of different technologies and management practices, cassava productivity can vary from 8 to $25 \mathrm{t} / \mathrm{ha}$ (Silva \& Santos, 2000). The Brazilian Northeastern Region stands out as the greatest produc- ing region, with a $59 \%$ share of the country's cassavagrowing area and $46 \%$ of the country's yield, on average (Cavalcanti \& Araújo, 2000). In different producing regions, the crop is infested by a large number of arthropods, some of which cause considerable damage, as, for example, Erinnyis ello ello L., Phenacoccus spp., and Mononychellus tanajoa (Bondar) (Farias, 1991; Bellotti et al., 1999). Among these, M. tanajoa constitutes one of the major problems for the crop in the Northeast Region (Moraes \& Flechtmann, 1981). 
The cassava green mite $M$. tanajoa occurs preferably in the apical bud of the plant. Infested leaves become chlorotic, do not attain normal development, with a usually distorted growth, and may fall progressively from top to bottom. Attacked stalks lose their green color and become coarse and brownish, with a furrowed bark. The plant may completely exhaust its reserves and die (Flechtmann, 1989; Gallo et al., 2002). In the back country of the State of Pernambucano, infestations occur with greater intensity from July to November, and may cause root yield losses in the order of $51 \%$ (Veiga, 1985).

Several tactics are used in the control of cassava green mite, such as: resistant cultivars (Nukenine et al., 2000), cultural practices (Veiga, 1985; Toko et al., 1996), biological control using predators (Farias et al., 1981; Moraes, 1991), and entomopathogens, such as the fungus Neozygites sp. (Delalibera Jr. et al., 2000). Chemical control is economically not viable, due to the crop's low yield, long cycle, and to the limited resources of producers (Bellotti et al., 1999).

The use of entomopathogenic fungi is an important practice that should be incorporated into integrated management, with the objective of reducing the populations of pest insects and mites in economically important crops (Alves, 1998). Within this context, Odongo et al. (1998) mentioned the potential for controlling M. tanajoa using the entomopathogenic fungus Hirsutella thompsonii Fisher, as well as the use of Entomophthora spp., Beauveria bassiana (Bals.) Vuill., and Metarhizium anisopliae (Metsch.) Sorok. (Odindo, 1992).

In a paper involving different control methods against the mite Brevipalpus spp. in Mexico, Acevedo \& Rosas (2000) concluded that control with $H$. thompsonii was superior to organophosphate chemical products. The fungus significantly reduced populations and the damage caused by the mites Brevipalpus phoenicis Geijskes and B. obovatus Donnadieu in citrus. Neozygites sp. epizootics are also frequent in $M$. tanajoa populations (Delalibera Jr. et al., 1992; Yaninek et al., 1996; Elliot et al., 2000). Several studies involving this fungus have been conducted; however, differently from $M$. anisopliae and B. bassiana, its challenging production on artificial medium makes it difficult to use it in green mite biological control programs (Oduor et al., 1996; Leite et al., 2000).

The fungi $B$. bassiana and $M$. anisopliae have been studied recently for the control of tetranychid mites (Alves et al., 2002; Oliveira et al., 2002). Notwithstanding, these entomopathogens have not yet been studied for the control of the cassava green mite. Hence, the present research had the objective of evaluating the effect of different B. bassiana and M. anisopliae isolates on $M$. tanajoa in the laboratory.

\section{MATERIAL AND METHODS} Brazil.

The experiments were carried out in Recife - PE,

\section{Mite rearing}

The rearing of Mononychellus tanajoa colonies in the laboratory was developed on cultivar Santo Estevão cassava plants, Manihot esculenta, planted in plastic pots containing soil and cattle manure at a 2:1 ratio. One 10$\mathrm{cm}$ plant cutting was placed in each pot; pots were maintained in the greenhouse. After 20 to 30 days, the plants were taken to the laboratory to be infested with mites. This process was repeated every seven days to maintain plant quality and to ensure a stock colony of mites. The pots containing infested plants were maintained in the laboratory at a temperature of $26 \pm 1^{\circ} \mathrm{C}, 63 \pm 5 \%$ relative humidity, and 12-hour photophase.

\section{Obtaining and production isolates}

The Metarhizium anisopliae and Beauveria bassiana isolates came from the fungus culture collection of the Insect Pathology Laboratory at the Plant Protection Division of UFRPE (Table 1). The isolates were plated into Petri dishes containing potato-dextrose-agar + streptomycine sulfate and incubated in a B.O.D. chamber at $26 \pm 1{ }^{\circ} \mathrm{C}$ and a 12-hour photophase for seven days. Next, they were reinvigorated on third-instar Diatraea saccharalis $(\mathrm{F}$.) caterpillars in order to maintain the pathogens' virulence. The isolates were later stored in glass vials containing PDA culture medium and Nujol ${ }^{\circledR}$ oil; in order to be used in the experiments, they were multiplied in plates containing complete culture medium (CM), consisting of yeast extract, glucose, minerals, agar, and water, according to Alves et al. (1998). Conidial viability was verified under the optical microscope, by means of the percentages of germinated and non-germinated conidia $24 \mathrm{~h}$ after plating on PDA + antibiotic and incubation for $24 \mathrm{~h}$ in a B.O.D. chamber at the same temperature and photophase previously mentioned.

\section{Selection of the most pathogenic isolates}

Ten M. anisopliae and $10 \mathrm{~B}$. bassiana isolates were used (Table 1). One experiment was installed for each fungus, in a completely randomized design, consisting of the isolates and one control with 5 replicates; each plot consisted of 20 mites, totaling 100 mites per treatment. The suspensions were prepared by adding $15 \mathrm{~mL}$ of sterilized distilled water plus Tween 80 at $0.01 \%$ to the conidia. The suspensions were filtered through sterilized gauze; counts were made in a Neubauer chamber, and the suspensions were standardized at $10^{8}$ conidia $\mathrm{mL}^{-1}$. Cassava leaf discs $3.5 \mathrm{~cm}$ in diameter were inoculated with the pathogen by immersion in $20 \mathrm{~mL}$ of the suspension for 5 seconds. The discs were then placed in Petri dishes containing two layers of filter paper circles, moistened with distilled water 
Table 1 - Hosts and origins of Metarhizium anisopliae and Beauveria bassiana isolates used on Mononychellus tanajoa in laboratory experiments.

\begin{tabular}{|c|c|c|}
\hline Isolates & Hosts & Source \\
\hline \multicolumn{3}{|c|}{ M. anisopliae } \\
\hline E9 & Deois flavopicta (Stal) & ESALQ-USP (Piracicaba - SP) \\
\hline 866 & Atta sp. & Goiânia - GO \\
\hline 1022 & Phyllophaga sp. & ESALQ-USP (Piracicaba - SP) \\
\hline CG 423 & Schistocerca pallens (Thunberg) & CENARGEN (Brasília - DF) \\
\hline 3027 & Deois flavopicta & ESALQ-USP (Piracicaba - SP) \\
\hline 860 & Scarabaeidae & ESALQ-USP (Piracicaba - SP) \\
\hline IPA 204 & Mahanarva posticata $(\mathrm{Stal})$ & IPA Company (Recife - PE) \\
\hline CG 321 & Cerotoma arcuata (Olivier) & CENARGEN (Brasília - DF) \\
\hline PL 47 & Mahanarva posticata & ESALQ-USP (Piracicaba - SP) \\
\hline 1189 & Soil sample & ESALQ-USP (Piracicaba - SP) \\
\hline \multicolumn{3}{|c|}{ B. bassiana } \\
\hline 512 & Solenopsis invicta (Buren) & ESALQ-USP (Piracicaba - SP) \\
\hline 561 & Solenopsis invicta & ESALQ-USP (Piracicaba - SP) \\
\hline CG 001 & Deois flavopicta & CENARGEN (Brasília - DF) \\
\hline 634 & Solenopsis invicta & ESALQ-USP (Piracicaba - SP) \\
\hline 604 & Soil sample & ESALQ-USP (Piracicaba - SP) \\
\hline 447 & Solenopis invicta & ESALQ-USP (Piracicaba - SP) \\
\hline IPA 198 & Cosmopolites sordidus (Germar) & IPA Company (Recife - PE) \\
\hline 645 & Soil sample & ESALQ-USP (Piracicaba - SP) \\
\hline 635 & Solenopsis invicta & ESALQ-USP (Piracicaba - SP) \\
\hline IPA 205 & Cosmopolites sordidus & IPA Company (Recife - PE) \\
\hline
\end{tabular}

and left to dry for twenty minutes in a laminar flow chamber. Adult mites aged $0-24 \mathrm{~h}$ after emergence from the stock colony were transferred to the arenas with a brush; twenty females per leaf were placed on the abaxial surface of the leaf. The females were sexed visually, by observation of the shape of the opisthosoma, which is round in females but different in males, that have funnel-shaped opisthosomas. The discs were placed and centralized onto polyethylene dishes $9 \mathrm{~cm}$ in diameter and $1.5 \mathrm{~cm}$ tall with a pin previously attached to the dish with silicone glue; the dishes contained $30 \mathrm{~mL}$ distilled water, which served as a physical barrier for the mites and to maintain leaf disc turgidity; the water level was completed daily.

Leaves were replaced on the fifth day after installation to ensure the quality of the substrate, and evaluations were carried out for eight days. The dead mites were placed in a wet chamber to confirm the causal agent and to determine confirmed mortality.

The daily mortality values were accumulated during the experiments to allow $\mathrm{LT}_{50}$ calculation, by Probit analysis, using the Mobae computer program (Haddad et al., 1995). The mite mortality data were submitted to analysis of variance using $\mathrm{F}$ test and the means were compared by Tukey test $(P \leq 0.05)$ using the Sanest (version 3.0) software package.

\section{Lethal Concentration Estimation}

The 645 B. bassiana and CG 321 M. anisopliae isolates, identified as the most pathogenic in the previous stage based on mortality and smaller $\mathrm{LT}_{50}$ observed against the cassava green mite, were used at the concentrations of $1 \times 10^{4}, 10^{5}, 10^{6}, 10^{7}$, and $10^{8}$ conidia $\mathrm{mL}^{-1}$ for $\mathrm{LC}_{50}$ determination. The experiments were conducted as a completely randomized experimental design, consisting of six treatments and five replicates containing $20 \mathrm{M}$. tanajoa females each, totaling 100 mites per treatment. The same methodology employed in the isolate selection experiment was used for disc and suspension preparation, as well as for suspension application, conidial viability determination, mite transfers, and evaluations.

\section{RESULTS AND DISCUSSION}

\section{Selection of the most pathogenic isolates}

Conidia viability for the $M$. anisopliae and $B$. bassiana isolates was higher than $95 \%$. The total mortality percentage caused by $B$. bassiana isolates varied from 13.0 to $97.0 \%$; confirmed mortality varied from 9.0 to $91.0 \%$, and $\mathrm{LT}_{50}$ values ranged from 4.2 to 17.0 days. Isolate 645 caused the highest total mortality $(97.0 \%)$ and confirmed mortality percentages $(91.0 \%)$, and the 
shortest $\mathrm{LT}_{50}$ (4.2 days) (Table 2). These values are similar to those obtained by Tamai (1997) for the mite Tetranychus urticae Koch, with a variation from 5.5 to $100 \%$ in total mortality and from 4.2 to $73.3 \%$ in confirmed mortality, using Beauveria spp. isolates at a concentration of $5 \times 10^{8}$ conidia $\mathrm{mL}^{-1}$. Also, Oliveira et al. (2002), working with $B$. bassiana isolates at $10^{8}$ conidia $\mathrm{mL}^{-1}$ and the red mite Oligonychus yothersi (McGregor), verified a variation in total mortality from 77 to $98 \%$ and a confirmed mortality from 19 to $75 \%$.

With regard to M. anisopliae, the total mortality percentage obtained for isolates of this fungus ranged from 12.0 to $45.0 \%$, confirmed mortality ranged from 8.0 to $45.0 \%$, and $\mathrm{LT}_{50}$ ranged from 8.6 to 18.4 days (Table $3)$. When these values are compared to those obtained for B. bassiana, M. anisopliae was less pathogenic to Mononychellus tanajoa; the M. anisopliae isolate CG 321 was the most efficient, providing a $45.0 \%$ confirmed mite mortality with an $\mathrm{LT}_{50}$ of 8.6 days. These results are better than those obtained by Tamai (1997), who evaluated M. anisopliae against $T$. urticae; the author obtained low pathogenicity against the mite, achieving only $4.2 \%$ confirmed mortality.

Even though using a concentration of $2.27 \times 10^{6}$ conidia $\mathrm{mL}^{-1}$, Albuquerque et al. (2000), during an evaluation of M. anisopliae pathogenicity over Brevipalpus

Table 2 - Total mortality and confirmed mortality percentages (Mean $\pm \mathrm{SE}$ ) of Mononychellus tanajoa females by Beauveria bassiana isolates at a concentration of $1 \times 10^{8}$ conidia $\mathrm{mL}^{-1}$ and Lethal Time $\left(\mathrm{LT}_{50}\right)$, in the laboratory. $26.5 \pm 0.6^{\circ} \mathrm{C}$, $78.4 \pm 4.2 \% \mathrm{RH}$, and 12-hour photophase.

\begin{tabular}{|c|c|c|c|c|c|}
\hline Isolate & Mortality ${ }^{1}$ total & Mortality ${ }^{1}$ confirmed & LT50 e CI (days) ${ }^{2}$ & Regression equation & Calculated $\chi^{2}$ \\
\hline 645 & $97.0 \pm 1.2 \mathrm{a}$ & $91.0 \pm 3.3 \mathrm{a}$ & $4.2(3.8-4.7)$ & $Y=-0.7+8.9 \log x$ & $27.6 *$ \\
\hline 447 & $86.0 \pm 4.8 \mathrm{ab}$ & $80.0 \pm 6.3 \mathrm{ab}$ & $4.7(4.2-5.3)$ & $Y=0.7+6.4 \log x$ & $26.6^{*}$ \\
\hline CG 001 & $83.0 \pm 5.2 \mathrm{ab}$ & $77.0 \pm 4.1 \mathrm{ab}$ & $5.3(4.8-5.8)$ & $Y=-0.6+7.8 \log x$ & $27.4 *$ \\
\hline IPA 198 & $83.0 \pm 7.0 \mathrm{ab}$ & $71.0 \pm 6.0 \mathrm{ab}$ & $5.2(4.6-5.8)$ & $Y=-0.2+7.2 \log x$ & $35.2 *$ \\
\hline 561 & $61.0 \pm 10.7 b c$ & $56.0 \pm 10.7 \mathrm{bc}$ & $6.3(5.5-7.1)$ & $Y=1.5+4.3 \log x$ & $16.2 *$ \\
\hline IPA 205 & $50.0 \pm 5.5 \mathrm{c}$ & $43.0 \pm 6.0 \mathrm{c}$ & $7.12(5.9-8.4)$ & $Y=2.0+3.4 \log x$ & $14.5^{*}$ \\
\hline 604 & $48.0 \pm 5.1 \mathrm{c}$ & $40.0 \pm 4.7 \mathrm{c}$ & $7.7(6.9-8.6)$ & $Y=0.1+5.6 \log x$ & $8.6 \mathrm{~ns}$ \\
\hline 512 & $38.0 \pm 4.0 \mathrm{~cd}$ & $35.0 \pm 4.4 \mathrm{~cd}$ & $8.7(7.6-10.0)$ & $Y=-0.7+6.1 \log x$ & $8.3 \mathrm{~ns}$ \\
\hline 634 & $36.0 \pm 7.3 \mathrm{~cd}$ & $29.0 \pm 6.2 \mathrm{~cd}$ & $8.9(7.5-10.4)$ & $Y=-0.5+5.8 \log x$ & $10.6 \mathrm{~ns}$ \\
\hline 635 & $13.0 \pm 1.2 \mathrm{de}$ & $9.0 \pm 1.00 \mathrm{~d}$ & $17.0(11.3-25.4)$ & $Y=0.13+3.9 \log x$ & $2.4 \mathrm{~ns}$ \\
\hline Control & $6.00 \pm 2.9 \mathrm{e}$ & & - & - & - \\
\hline $\mathrm{CV}$ & $23.1 \%$ & $24.4 \%$ & & & \\
\hline
\end{tabular}

${ }^{1}$ Means ( \pm SE) followed by the same letter in the columns do not differ by Tukey test at $5 \%$.

${ }^{2} \mathrm{LT}_{50}$ Lethal Time; CI, Confidence Interval at $5 \%$; CV, Coefficient of Variation.

Table 3 - Total mortality and confirmed mortality percentages (Mean \pm SE) of Mononychellus tanajoa females by Metarhizium anisopliae isolates at a concentration of $1 \times 10^{8}$ conidia $\mathrm{mL}^{-1}$ and Lethal Time $\left(\mathrm{LT}_{50}\right)$, in the laboratory. $26.1 \pm 0.7^{\circ} \mathrm{C}$, $79.5 \pm 5.9 \% \mathrm{RH}$, and 12-hour photophase.

\begin{tabular}{|c|c|c|c|c|c|}
\hline Isolate & Mortality ${ }^{1}$ total & Mortality ${ }^{1}$ confirmed & LT50 e CI (days) ${ }^{2}$ & Regression equation & Calculated $\chi^{2}$ \\
\hline CG 321 & $45.0 \pm 2.7 \mathrm{a}$ & $45.0 \pm 2.7 \mathrm{a}$ & $8.6(7.9-9.4)$ & $Y=0.7+4.7 \log x$ & $2.7 \mathrm{~ns}$ \\
\hline 1022 & $37.0 \pm 5.3 \mathrm{ab}$ & $32.0 \pm 4.8 \mathrm{ab}$ & $9.4(8.5-10.4)$ & $Y=-0.7+5.8 \log x$ & $3.1 \mathrm{~ns}$ \\
\hline 3027 & $35.0 \pm 4.4 \mathrm{abc}$ & $28.0 \pm 4.8 \mathrm{bc}$ & $9.9(8.6-11.3)$ & $Y=0.6+4.3 \log x$ & $3.3 \mathrm{~ns}$ \\
\hline 1189 & $25.0 \pm 4.4 \mathrm{bcd}$ & $20.0 \pm 4.4 \mathrm{bcd}$ & $12.1(8.7-16.7)$ & $Y=0.9+3.7 \log x$ & $8.0 *$ \\
\hline E9 & $21.0 \pm 1.0 \mathrm{bcde}$ & $19.0 \pm 1.8 \mathrm{bcd}$ & $12.0(9.4-15.2)$ & $Y=-0.4+5.0 \log x$ & $3.8 \mathrm{~ns}$ \\
\hline CG 423 & $19.0 \pm 4.5 \mathrm{cde}$ & $15.0 \pm 4.1 \mathrm{~cd}$ & $13.6(9.8-18.9)$ & $Y=0.2+4.2 \log x$ & $4.3 \mathrm{~ns}$ \\
\hline IPA 204 & $13.0 \pm 2.5 \mathrm{de}$ & $10.0 \pm 2.2 \mathrm{~d}$ & $16.4(11.9-22.6)$ & $Y=-0.4+4.4 \log x$ & $1.4 \mathrm{~ns}$ \\
\hline PL 47 & $13.0 \pm 1.2 \mathrm{de}$ & $10.0 \pm 1.5 \mathrm{~d}$ & $19.8(13.0-30.1)$ & $Y=0.12+3.7 \log x$ & $1.4 \mathrm{~ns}$ \\
\hline 866 & $12.0 \pm 2.5 \mathrm{de}$ & $10.0 \pm 2.7 \mathrm{~d}$ & $21.2(12.0-37.3)$ & $Y=0.4+3.4 \log x$ & $2.3 \mathrm{~ns}$ \\
\hline 860 & $12.0 \pm 3.7 \mathrm{de}$ & $8.00 \pm 2.0 \mathrm{~d}$ & $18.4(14.0-24.2)$ & $Y=-0.3+4.2 \log x$ & $0.6 \mathrm{~ns}$ \\
\hline Control & $7.00 \pm 1.2 \mathrm{e}$ & & - & - & - \\
\hline $\mathrm{CV}$ & $35.1 \%$ & $38.5 \%$ & & & \\
\hline
\end{tabular}

${ }^{1}$ Means $( \pm$ SE) followed by the same letter in the columns do not differ by Tukey test at $5 \%$.

${ }^{2} \mathrm{LT}_{50}$ Lethal Time; CI, Confidence Interval at 5\%; CV, Coefficient of Variation.

Sci. Agric. (Piracicaba, Braz.), v.61, n.6, p.659-664, Nov./Dec. 2004 
phoenicis Geijskes, also did not verify efficiency of the fungus over this mite; during their study, only $2.25 \%$ mortality occurred, and no conidiogenesis was observed.

\section{Lethal Concentration Estimation}

A relationship was verified between the increase in conidial suspension concentration and the increase in total mortality and confirmed mortality caused by the $B$. bassiana 645 and $M$. anisopliae CG 321 isolates, as well as with the $\mathrm{LC}_{50}$ values (Table 4 ). The total mortality caused by the $B$. bassiana isolate 645 at the concentration of $10^{4}$ conidia/mL was not different from the control; however, the other concentrations caused higher mortalities than the control, with a total mortality of $93.0 \%$ and a confirmed mortality of $83.0 \%$, at the concentration of $10^{8}$ conidia $\mathrm{mL}^{-1}$.

The $\mathrm{LC}_{50}$ for the $645 \mathrm{~B}$. bassiana isolate was $3.93 \times 10^{6}$ conidia $\mathrm{mL}^{-1}$, ranging from $2.67 \times 10^{4}$ to 7.36 $\times 10^{7}$ conidia $\mathrm{mL}^{-1}$ (Table 4). The $645 \mathrm{~B}$. bassiana isolate showed a lower $\mathrm{LC}_{50}$ than the CG321 M. anisopliae isolate, thus demonstrating that the first was more pathogenic than the second. Tamai et al. (1999), using the 447 $B$. bassiana isolate on females of the mite $T$. urticae, concluded that only at the concentration of $1 \times 10^{9}$ conidia $\mathrm{mL}^{-1}$ there was a total mortality higher than $50 \%$. Alves et al. (2002), evaluating the effect of B. bassiana isolate 447 on T. urticae at different concentrations, verified an $\mathrm{LC}_{50}$ of $1.26 \times 10^{7}$ conidia $\mathrm{mL}^{-1}$, therefore higher than the value obtained in this work with $B$. bassiana isolate 645 .
The $M$. anisopliae isolate CG 321 showed an $\mathrm{LC}_{50}$ of $7.44 \times 10^{8}$ conidia $\mathrm{mL}^{-1}$, varying from $1.97 \times 10^{8}$ to $6.51 \times 10^{9}$ conidia $\mathrm{mL}^{-1}$; At a concentration of $1 \times 10^{8}$ conidia $\mathrm{mL}^{-1}$, a total mortality of only $41.0 \%$ and a confirmed mortality of only $31.0 \%$ were obtained. Correia et al. (1998), studying M. anisopliae isolate $\mathrm{E}_{9}$ at concentrations of $7.5 \times 10^{5}$ to $7.5 \times 10^{8}$ conidia $\mathrm{mL}^{-1}$ on the cattle tick Boophilus microplus Canestrini, verified mortalities from 10.9 to $40.0 \%$, respectively; these values are also not very expressive for the highest concentration used. Hanchinal \& Manjunatha (2000), however, working with M. anisopliae at concentrations of $1.5 \times 10^{4}, 1.5 \times 10^{6-}$, and $1.5 \times 10^{8}$ conidia $\mathrm{mL}^{-1}$ on Tetranychus neocaledonicos Andre adults, verified that the fungus at the highest concentration caused a mite mortality of $92.9 \%$.

With regard to the performance variability of different isolates, Sosa Gómez \& Alves (1983) verified a high enzymatic activity in more virulent isolates of $M$. anisopliae from several Brazilian regions, and mentioned that they are probably associated with the presence of enzymes that influence the penetration process of the fungus (St Leger et al., 1988; De La Rosa et al., 1997), as well as with toxins such as destruxins and beauvericin present, respectively, in M. anisopliae and B. bassiana, which vary in different isolates (Roberts \& Krasnoff, 1998). Considering that the use of entomopathogenic fungi should be viewed as a component of integrated pest management, the results here obtained suggest that $B$. bassiana isolate 645 should be used in control programs against the cassava green mite $M$. tanajoa.

Table 4 - Total mortality and confirmed mortality percentages (Mean \pm SE) of Mononychellus tanajoa females by the Beauveria bassiana 645 and Metarhizium anisopliae CG 321 isolates, at the concentrations of $1 \times 10^{4}, 10^{5}, 10^{6}, 10^{7}$, and $10^{8}$ conidia $\mathrm{mL}^{-1}$, and Lethal Concentration $\left(\mathrm{LC}_{50}\right)$. Temperature of $25.4 \pm 0.7^{\circ} \mathrm{C}, 64.7 \pm 2.2 \% \mathrm{RH}$, and 12-hour photophase.

\begin{tabular}{|c|c|c|c|c|c|c|}
\hline Isolates & Concentration (conidia/mL) & Mortality $^{1}$ total & Mortality ${ }^{1}$ confirmed & $\mathrm{LC}_{50}\left(\right.$ conidia $\left.\mathrm{mL}^{-1}\right) \mathrm{IC}^{2}$ & $b^{3}$ & $\chi^{2,4}$ \\
\hline \multirow[t]{5}{*}{645} & $10^{8}$ & $93.0 \pm 3.7 \mathrm{a}$ & $83.0 \pm 2.0 \mathrm{a}$ & $3.9 \times 10^{6}$ & 0.7 & $5.5 \mathrm{~ns}$ \\
\hline & $10^{7}$ & $4.0 \pm 2.4 \mathrm{~b}$ & $38.0 \pm 2.0 \mathrm{~b}$ & $\left(2.6 \times 10^{4}-7.3 \times 10^{7}\right)$ & & \\
\hline & $10^{6}$ & $32.0 \pm 3.0 \mathrm{c}$ & $26.0 \pm 2.4 \mathrm{c}$ & & & \\
\hline & $10^{5}$ & $26.0 \pm 1.8 \mathrm{~cd}$ & $19.0 \pm 2.4 \mathrm{c}$ & & & \\
\hline & $10^{4}$ & $19.0 \pm 3.6 \mathrm{de}$ & $8.00 \pm 1.2 \mathrm{~d}$ & & & \\
\hline Control & & $7.00 \pm 2.0 \mathrm{e}$ & & & & \\
\hline $\mathrm{CV}$ & 17.36 & & 13,24 & - & & - \\
\hline \multirow[t]{5}{*}{ CG 321} & $10^{8}$ & $41.0 \pm 3.3 \mathrm{a}$ & $31.0 \pm 2.4 \mathrm{a}$ & $7.4 \times 10^{8}$ & 0.4 & $4.7 \mathrm{~ns}$ \\
\hline & $10^{7}$ & $26.0 \pm 6.5 \mathrm{ab}$ & $19.0 \pm 5.3 \mathrm{ab}$ & $\left(1.9 \times 10^{8}-6.5 \times 10^{9}\right)$ & & \\
\hline & $10^{6}$ & $21.0 \pm 5.5 \mathrm{bc}$ & $13.0 \pm 3.9 \mathrm{bc}$ & & & \\
\hline & $10^{5}$ & $12.0 \pm 2.5 \mathrm{bc}$ & $7.00 \pm 1.2 \mathrm{bc}$ & & & \\
\hline & $10^{4}$ & $9.00 \pm 1.8 \mathrm{bc}$ & $3.00 \pm 1.2 \mathrm{c}$ & & & \\
\hline Control & & $7.00 \pm 2.0 \mathrm{c}$ & & - & & - \\
\hline $\mathrm{CV}$ & & $47.0 \%$ & $47.9 \%$ & & & \\
\hline
\end{tabular}

${ }^{1}$ Means ( \pm SE) followed by the same letter in the columns do not differ by Tukey test at $5 \%$.

${ }^{2} \mathrm{LC}_{50}$, Lethal Concentration; CI, Confidence Interval at 5\%; CV, Coefficient of Variation.

${ }^{3} \mathrm{~b}$ Regression line slope coefficient

${ }^{4} \chi^{2}=\chi^{2}$ Test

Sci. Agric. (Piracicaba, Braz.), v.61, n.6, p.659-664, Nov./Dec. 2004 


\section{CONCLUSION}

B. bassiana isolates tested are more efficient than the $M$. anisopliae isolates for utilization in integrated management of the cassava green mite M. tanajoa.

\section{ACKNOWLEDGEMENTS}

To CAPES, for a Master's degree scholarship granted to the first author of this work. To M.Sc. Josinélia Fernandes Ferreira for her help during the entire period when the experiments were carried out.

\section{REFERENCES}

ACEVEDO, J.L.R.; ROSAS, L.S. Controle biológico de Brevipalpus spp. en Citrus aurantifolia en Guerrero, México. Manejo Integrado de Plagas, v.55, p.56-59, 2000.

ALBUQUERQUE, F.A.; ARANTES, A.M.V.T.; CORREIA. do C.B. Patogenicidade de fungos para o ácaro da leprose Brevipalpus phoenicis (Geijskes, 1939) (Acari: Tenuipalpidae). Acta Scientiarum, v.22, p.969971, 2000.

ALVES, S.B. Fungos entomopatogênicos. In: ALVES, S.B. (Ed.) Controle microbiano de insetos. 2.ed. Piracicaba: FEALQ, 1998. cap.11, p.289-381.

ALVES, S.B.; ALMEIDA, J.E.M.; MOINO JR., A.; ALVES, L.F.A. Técnicas de laboratório. In: ALVES, S.B. (Ed.) Controle microbiano de insetos. 2.ed. Piracicaba: FEALQ, 1998. cap.20, p.637-771.

ALVES, S.B.; ROSSI, L.S.; LOPES, R.B.; TAMAI, M.A.; PEREIRA, R.M. Beauveria bassiana yeast phase on agar medium and its pathogenicity against Diatraea saccharalis (Lepidoptera: Crambidae) and Tetranychus urticae (Acari: Tetranychidae). Journal of Invertebrate Pathology, v.81, p.70-77, 2002

BELLOTTI, A.C.; SMITH, L.; LAPOINTE, L.S. Recent advances in cassava pest management. Annual Review of Entomology, v.44, p.343-370, 1999.

CAVAlCANTI, J.; ARAÚJO, G.G.L. de. Parte área da mandioca na alimentação de ruminantes na região semi-árida. Petrolina: Embrapa Semi Árido, 2000. 21p. (Circular Técnico, 57).

CORREIA, A. do C.B.; FIORIN, A.C.; MONTEIRO, A.C.; VERÍSSIMO, C.J. Effects of Metarhizium anisopliae on the tick Boophilus microplus (Acari: Ixodidade) in stabled cattle. Journal of Invertebrate Pathology, v.71, p.189-191, 1998.

DELALIBERA JR., I.; GOMEZ, D.R.S.; MORAES, G.J. de. Infection of Mononychellus tanajoa (Acari: Tetranychidae) by the fungus Neozygites sp. (Entomophthorales) in northeastern Brazil. Florida Entomologist, v.75, p.145-147, 1992.

DELALIBERA JR., I.; MORAES, G.J. de; LAPOINTE, S.L.; SILVA, C.A.D. da; TAMAI, M.A. Temporal variability and progression of Neozygites sp. (Zygomycetes: Entomophthorales) in populations of Mononychellus tanajoa (Bondar) (Acari: Tetranychidae). Anais da Sociedade Entomológica do Brasil, v.29, p.523-536, 2000.

DE LA ROSA, W.; ALATORRE, R.;TRUJILlO, J.; BARRERA, J. Virulence of Beauveria bassiana (Deuteromycetes) strains against the coffee berry borer (Coleoptera: Scolytidae). Journal of Economic Entomology, v.90, p.1534-1538, 1997.

ELLIOT, S.L.; MORAES, G.J. de, DELALIBERA JR., I.; SILVA, C.A.D. da; TAMAI, M.A.; MUMFORD, J.D. Potential of the mite-pathogenic fungus Neozygites floridana (Entomophthorales: Neozygitaceae) for control of the cassava green mite Mononychellus tanajoa (Acari: Tetranychidae). Bulletin of Entomological Research, v.90, p.191-200, 2000.

FARIAS, A.R.N. Insetos e ácaros pragas associados à cultura da mandioca no Brasil e meios de controle. Cruz das Almas: EMBRAPA, CNPMF, 1991. 47p. (Circular Técnica, 14).

FARIAS, A.R.N.; FLECHTMANN, C.H.W.; MORAES, G.J. de; MCMURTY, J.A. Predadores de ácaro verde da mandioca no nordeste do Brasil. Pesquisa Agropecuária Brasileira, v.16, p.313-317, 1981.

FLECHTMANN, C.H.W. Ácaros de importância agrícola. 6.ed. São Paulo: Nobel, 1989. 189p.
FNP CONSULTORIA E COMÉRCIO. Anuário Estatístico da Agricultura Brasileira. São Paulo, 2002. 435p.

GALLO, D.; NAKANO, O.; SILVEIRA NETO, S.; CARVALHO, R.P.L.; BAPTISTA, G.C. de.; BERTI FILHO, E.; PARRA, J.R.P.; ZUCCHI, R.A.; ALVES, S.B.; VENDRAMIN, J.D.; MARCHINI, L.C.; LOPES, J.R.S.; OMOTO, C. Entomologia agrícola. Piracicaba: FEALQ, 2002. 920p.

HADDAD, M.L.; MORAES, R.C.B.; PARRA, J.R.P. Modelos bioestatísticos aplicados á entomologia (MOBAE). Manual. Piracicaba: ESALQ/USP, 1995. 44p.

HANCHINAL, S.G.; MANJUNATHA, M. Metarhizium anisopliae (Metsch.) Sor. On Tetranychus neocaledonicos Andre and its predator Amblyseius ovalis Evans. Karnataka Journal of Agricultural Sciences, v.13, p.454-456, 2000.

LEITE, L.G.; SMITH, L.; MORAES, G.J. de; ROBERTS, D.W. In vitro production of hyphal bodies of the mite pathogenic fungus Neozygites floridana. Mycologia, v.92, p.201-207, 2000.

MORAES, G.J. Controle biológico de ácaros fitófagos. Informe Agropecuário, v.15, p.55-62, 1991.

MORAES, G.J. de; FLECHTMANN, C.H.W. Ácaros fitófagos no nordeste do Brasil. Pesquisa Agropecuária Brasileira, v.2, p.177-186, 1981.

NUKENINE, E.N.; HASSAN, A.T.; DIXON, A.G.O. Influence of variety on the within-plant distribution of cassava green spider mite (Acari: Tetranychidae), and leaf anatomical characteristics and chemical components in relation to varietal resistance. International Journal of Pest Management, v.46, p.177-186, 2000.

ODINDO, M.O. Future prospects for the application of insect pathogens as a component of integrated pest management in tropical root crops. Biocontrol Science and Technology, v.2, p.179-191, 1992.

ODONGO, B.; ODINDO, M.O.; BROWNBRINDGE, M.; KUMAR, R. Comparative biological efficacy of Hirsutella thompsonii and Neoseiulus teke for cassava mite Mononychellus tanajoa suppression. Biocontrol Science and Technology, v.8, p.345-355, 1998.

ODUOR, G.I.; MORAES, G.J. de; VAN DER GEEST, L.P.S.; YANINEK, J.S. Production and germination of primary conidia of Neozygites floridana (Zygomycetes: Entomophthorales) under constant temperatures, humudities, and photoperiods. Journal of Invertebrate Pathology, v.68, p.213-222, 1996.

OLIVEIRA, R.C. de; ALVES, L.F.A.; NEVES, P.M.O.J. Suscetibilidade de Oligonychus yothersi (Acari: Tetranychidae) ao fungo Beauveria bassiana. Scientia Agricola, v.59, p.187-189, 2002.

ROBERTS, D.W.; KRASNOFF, S.B. Toxinas e enzimas de fungos entomopatogênicos. In: ALVES, S.B. (Ed.) Controle microbiano de insetos. 2.ed. Piracicaba: FEALQ, 1998. cap. 32, p.967- 985.

SILVA, A.D.A.; SANTOS, E.O. dos. Cultura da mandioca. IPA Responde, n.14, p.1-4, 2000.

SOSA-GÓMEZ, D.R.; ALVES, S.B. Caracterizacion de once aislamiento de Metarhizium anisopliae (Metsch.) Sorok. I Estandarizacion, virulência y actividade enzimática.CIRPON. Revista de Investigacíon, v.1, p.83-101, 1983.

ST. LEGER, R.J.; DURRANDS, P.K.; CHARNLEY, A.K.; COOPER, R.M. Role of extracellular chymoelastase in the virulence of Metarhizium anisopliae for Manduca sexta. Journal of Invertebrate Pathology, v.52, p.285-293, 1988.

TAMAI, M.A. Avaliação de fungos entomopatogênicos para o controle de Tetranychus urticae Koch. Piracicaba: USP/ESALQ, 1997. 86p. (Dissertação - Mestrado).

TAMAI, M.A.; ALVES, S.B.; NEVES, P.J. Patogenicidade de Beauveria bassiana (Bals.) Vuill. ao ácaro Tetranychus urticae Koch. Scientia Agricola, v.56, p.255-258, 1999.

TOKO, M.; O-NEIL, R.J.; YANINEK, J.S. Development, reproduction and survival of Mononychellus tanajoa (Bondar) (Acari: Tetranychidae) on cassava grown under soils of different levels of nitrogen. Experimental and Applied Acarology, v.20, p.405-419, 1996.

VEIGA, A.F.S.L. Aspectos bioecológicos e alternativas de controle do ácaro verde da mandioca Mononychellus tanajoa (Bondar, 1938) (Acarina: Tetranychidae) no estado de Pernambuco. Piracicaba: USP/ESALQ, 1985. 137p. (Tese - Doutorado).

YANINEK, J.S.; SAIZONOU, S.; ONZO, A.; ZANNOU, I.; GNAVOSSOU, D. Seasonal and habitat variability in the fungal pathogens, Neozygites floridana and Hirsutella thompsonii, associated with cassava mites in Benin, west Africa. Biocontrol Science and Technology, v.6, p.23-33, 1996.

Received July 04, 2003

Accepted September 13, 2004 